\title{
材料の不確定性を有する履歴振動系のエネルギ一応答のための 解析的アプローチ \\ AN ANALYTICAL APPROACH TO ENERGY RESPONSE OF HYSTERETIC STRUCTURES CONSISTED OF UNCERTAINTY MATERIALS
}

\author{
洪起*, 高梨晃一** \\ $\mathrm{Ki} \mathrm{KOH}$ and Koichi TAKANASHI
}

\begin{abstract}
The main objectives of this study are to investigate the effects of random variability in steel yield stress and strain hardening modulus on energy response of structures under earthquake loading.

Up to now, all of studies concerning the effects of random variability in material property on dynamic response are based on methodology of a Monte Carlo simulation. This paper describes the analytical method to estimate the statistics of energy response for hysteretic structures consisted of uncertainty materials.
\end{abstract}

Keywords : energy response, random variability, probability of safety, uncertainty materials エネルギー応答, ランダム変動, 安全の確率, 不確定性材料

\section{§1.はじめに}

構造物の耐震設計における確率論手法の応用に関する 研究は, Conell, Lind, Ang らによる 2 次モーメント 法の開発以来, 盛んに行われ, 非常に多くの成果を挙げ ている(1) 4), 13), (4)。特に, 最近地震動の不確定性の影響に 関する研究の他に, 材料の不確定性が構造物の応答值に

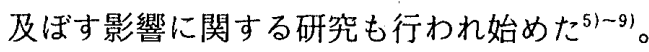

Sue (5) は, 外力之構造物の抵抗に関する変動を定 量化し, 構造物の地震波による動的応答值に確率論的概 念を導入することによって, 構造物の信頼性評価におけ る潜在的不確定性について論じた。O'Connor（6）は, 地震入力波の不確定性の他に, 質量, 剛性, さらに, 粘 性減衰, 降伏応力等の構造特性の不確定性が履歴構造物 の動的応答值に及ぼす影響を広範な数值解析によって調 查し, 構造特性の変動は非弾性応答值に重要な影響を及 ぼすという結論を述べた。桑村”は, 降伏応力の変動が 骨組の靱性率に及ぼす影響を調べ，鋼材の降伏比が小さ い場合，鋼材は高い勒性率を示すと述べた。さらに，柱 弾性, 梁降伏型の 6 層 3 スパン骨組のモンテカルロシ ミュレーションによる数値解析結果から, 降伏強度の不 確定性は骨組の静的および動的な勒性率ばかりでなく， 崩壊機構にも重要な影響を及ぼすことを指摘し, 部材降
伏強度の変動係数が大きくなると, 局部的崩壊の可能性 を高め, さらにその変動係数が $2.5 \%$ から $5.0 \%$ ある 場合, 骨組の全体の崩壊機構の発生に及ぼす影響は, 一地 震入力波の不確定性よりも大きくなることを指摘し $た^{81}$ 。Elnashai and Chryssanthopoulos は， 1 層骨組の 柱と梁の不確定性が静的荷重下における骨組の最大耐 力, 勒性率, さらにエネルギー吸収能力等に及ぼす影響 をモンテカルロシミュレーション手法によって解析を行 い, それぞれの降伏応力の変動係数と相関関数の度合い がこれらの応答値に大きな影響を与えると述べた9)。

次に, このような不確定性パラメー夕を含む履歴構造 物の動的応答解析のための方法論について簡単に述べる。 一般に, 不確定性を含む動的解析に関する問題は; 次 の 2 つに分類される。一つは, 構造特性（質量, 剛性, 减衰, 復元力等) が確定值で, 入力波がランダムな場合 であり，他は，その逆，すなわち構造特性がランダムで 入力波が確定波, 例えばEl Centro 波のような場合であ る。前者の問題の解法としては, (1) 微分方程式に基 づく解析的手法, (2) パワーバランス法, . (3) 等価線 形化法, (4) モンテカルロシミュレーション等の 4 つ の主な方法がある。一方, 後者の解法としては, (1) テー ラー展開による近似方法, (2) 攝動法等の 2 つの主な
* 東京大学生産技術研究所 助手·工博

** 東京大学生産技術研究所 教授・工博
Research Assoc, Institute of Industrial Science, Univ. of Tokyo, Dr. Eng. Prof., Institute of Industrial Science, Univ. of Tokyo, Dr. Eng. 


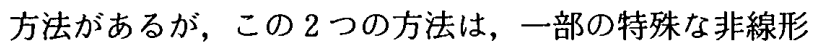
問題を除いてほとんど線形問題に限定される。そのため, 前述のような降伏応力の変動が構造物の応答值に及ぼす 影響等を解析する問題は, モンテカルロシミュレーショ ン手法に頼らざるをえない。

一般に, 構造物の抵抗力の変動は構造部材の材料強度 之断面形状等のばらつきに依存する。本論は, これらの 不確定要因のうちで材料強度のばらつきのみを抵抗力の 不確定要因とみなしたときの動的応答値に及ぼす影響を 調べたもので, 解析手法として等価線形化法を用いる。 ここで述べ等価線形化法は従来の方法とは多少異な り, 不確定性要素を含む復元力特性をフーリエ級数展開 の第 1 項で近似した複素関数で表現する手法を採用す る。本論の目的は，このような等価線形化法に基づいて 次の 2 つの確率量を解析的に評価しようとするものであ る。

（1）構造特性（降伏応力と加工硬化係数）がランダム 性を有するときの, 確定波地震入力による構造物系への エネルギー入力の統計量の評価

（2）構造特性のランダム性が構造物の安全の確率に及 ぼす影響の定量的評価

なお，本論では構造物の損傷に密接に関係すると思わ れる塑性変形によって吸収されるエネルギー入力のみに 注目する。

\section{§2. 不確定性を有する構造部材の復元力特性の確率的 モデル化}

まず，鋼材の応力ひずみ関係の確率的モデル化につい て述べる。鋼材の単調引張試験による応力ひずみ曲線は, 降伏点, 降伏棚, 加工硬化係数等を含む複雑な挙動を示 す。このような応力とひずみの関係を正確にモデル化す ることは大変困難なので, 本論では, Fig. 1 に示した Bilinear モデルで近似する。この Bilinear モデルは降 伏応力と加工硬化係数の 2 つのパラメターで表すことが できるから, 応力ひずみ曲線の確率モデルは降伏応力と 加工硬化係数の 2 つの確率変数で表される。

降伏応力の変動に関する統計的研究は, 日本, 英国な どにおいて盛んに行われ，降伏応力の分布関数は正規分 布で表されるという結論 ${ }^{21}$ 之対数正規分布で表されると

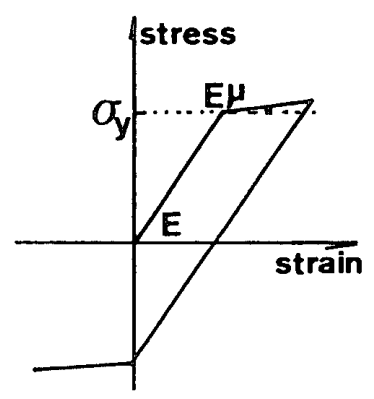

Fig. 1 Stress-Strain Model
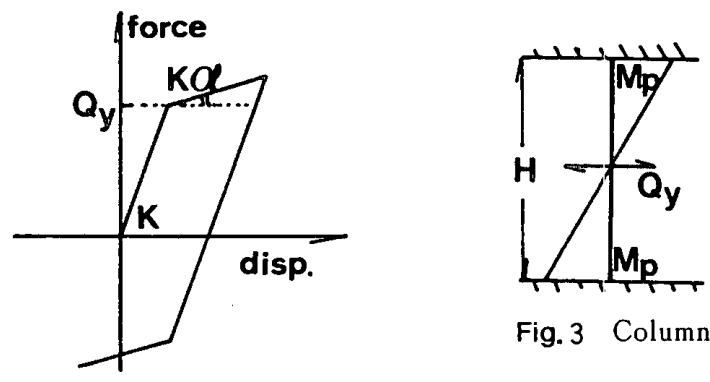

Fig. 3 Column

Fig. 2 Hysteretic Restoring Force Model

いう結論"1)を得ているが，ここでは簡絜であるという点 から正規分布を用いる。降伏応力の統計量は, 平均値亡 して $2.8 \mathrm{t} / \mathrm{cm}^{2}$ ，変動係数として 0.069 を用いる ${ }^{11 ! 。}$

一方，加工硬化係数に関する統計的研究はほとんどな されていないので，分布性状に関する情報はほよんどな い。それ故，本論では，情報が全くないという意味から 一様分布を仮定する。

結局，不確定性を有する鋼材の応力ひずみ曲線の確率 モデルは次のようになる。

$$
\left.\begin{array}{l}
\sigma_{y}=N\left(2.8 \mathrm{t} / \mathrm{cm}^{2}, 0.193 \mathrm{t} / \mathrm{cm}^{2}\right) \\
\mu=U(0.007 E, 0.012 E)
\end{array}\right\}
$$

ただし， $\sigma_{y}:$ 降伏応力

$\mu$ : 加工硬化係数 $(E$ に対する第 2 分岐勾配 の比)

$N(X, Y)$ : 正規分布 $(X:$ 平均, $Y$ : 標準偏差 $)$

$U(X, Y)$ : 一様分布 $(X: \text { 下限値, } Y \text { : 上限值 })^{\text {(i) }}$

$E:$ ヤグ率

次に，このような不確定性を有する鋼材からなる部材 の復元力特性の確率モデルについて述べる。

塑性設計において，全塑性モーメント $M_{\rho}$ と塑性断面 係数 $Z_{p}$ との間に次式が成立する。

$$
M_{p}=z_{p} \sigma_{y}
$$

また, Fig. 3 から次式が得られる。

$$
Q_{y}=\frac{2}{H} Z_{p} \sigma_{y}
$$

(2-3) 式の $Q_{y}$ は部材剪断力の降伏強度を表すから, 部材の復元力特性の確率モデルも応力ひずみ曲線同様 に，Bilinear モデルで表される（Fig. 2)。降伏強度 $Q_{y}$ と初期剛性に対する降伏後の剛性の比 $\alpha$ の統計量は次 式から得られる。

$$
\begin{array}{c|c}
E\left[Q_{y}\right]=\frac{2}{H} Z_{p} E\left[\sigma_{y}\right] & \\
\text { C.o.V. }\left[Q_{y}\right]=\mathrm{C} .0 . \mathrm{V} .\left[\sigma_{y}\right] & \ldots \ldots \ldots \ldots \ldots . . .(2-4) \\
E[\alpha]=E[\mu] & \\
\text { C.O.V. }[\alpha]=\mathrm{C} .0 . \mathrm{V} .[\mu] & \\
\text { ただし, } E(X): X \text { の平均値 } \\
\text { C.o.V. }(X): X \text { の変動係数 (Coefficient of Varia- } \\
\text { tion) }
\end{array}
$$

注）下限值と上限値の值は実験等から適当に決めた。 
（2-4）式は，不確定性を有する構造部材の復元力モデ ルを非常に単純化して, bilinear モデルで近似した場合 のパラメターの統計量を材料の降伏応力と加工硬化係数 の統計量から推定するための近似的評価式である。

\section{§3. 地震波入力を受ける履歴振動系の周波数応答解析}

本論は，前項で述べた不確定性を有する復元力特性を 持つ履歴振動系が確定地震波を受けたときの動的応答值 の統計量を解析的に得ようとするものである。このよう な履歴振動系の応答值の解析解を得るためには，釣合式 の非線形項を表す復元力特性をどのように表現するかが 重要な問題である。

Suzuki, Minai ${ }^{13)}$ は, 復元力特性を微分方程式型履歴 モデルで表現することによって，不確定地震波を受ける 履歴振動系の動的灾答值の統計量を解析的に得た。本論 では, 復元力を表す Bilinear モデルは確率変数で表現 されるから，まず確率変数を表す降伏強度と降伏後の剛 性をある值に固定した Bilinear モデルを想定する。次 に，これをフーリェ級数展開し，その第 1 項で近似する 手法を用いる ${ }^{18)}$ 。

Fig. 4 で示した多自由度系の $j$ 層の時間領域での運動 方程式は次式になる。

$$
\sum_{k=j}^{n} m_{k} \sum_{l=1}^{k} \ddot{X}_{l}+D_{j} \dot{X}_{j}+F_{j}\left(X_{j}, \quad t\right)=-\sum_{k=j}^{n} m_{k} \ddot{y}(t)
$$

ただし $m_{j}: j$ 層の質量

$K_{j}: j$ 層の剛性

$D_{j}=\frac{2 h}{\omega_{1}} K_{j}$

\section{$h:$ 粘性減衰常数, $\omega_{1}: 1$ 次振動数}

$F_{j}(X, t)$ : 降伏強度と降伏後の岡性比をある值に固定 したときの Bilinear モデル

$X_{j}: j$ 層の相対変位

$\ddot{y}(t)$ : 確定入力地震波

まず，入力地震波 $\ddot{y}(t)$ に含まれる周波数領域の $\omega$ 成分 の加速度振幅を持つ調和入力 $\ddot{Y}(\omega) e^{i \omega t}$ を想定したとき の (3-1) 式の解を考える。前述のように(3-1) 式の

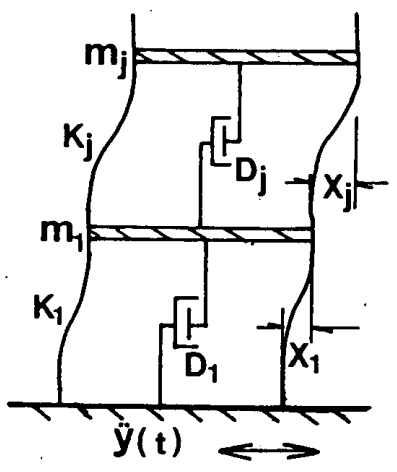

Fig. 4 MDOF Systems
Bilinear モデルをフーリエ級数展開の第 1 項で近似する 手法を採用すると, $j$ 層の相対変位振幅を $X_{j}(\omega) e^{i \omega t}$ と したときの Bilinear モデルは次のような棈円型履歴モ デルで表される。なお，本論では，FFTによる数値計 算を容易にするために複素座標系で表現する。

$$
F_{j}\left(X_{j}, \omega t\right)=X_{j}(\omega)\left(C_{j}-i S_{j}\right) e^{i \omega t} \ldots
$$

ただし, $i^{2}=-1$

$$
\begin{aligned}
& C_{j}=\frac{K_{j}}{\pi X_{j}(\omega)} \int_{0}^{2 \pi} F_{j}\left(X_{j}, \omega t\right) \cos \omega t d(\omega t) \\
& S_{j}=\frac{K_{j}}{\pi X_{j}(\omega)} \int_{0}^{2 \pi} F_{j}\left(X_{j}, \omega t\right) \sin \omega t d(\omega t)
\end{aligned}
$$

Bilinear モデルの場合の係数 $C_{j}, S_{j}$

$$
C_{j}\left(\dot{\widetilde{u}}_{j}\right)=\frac{K_{j}}{\pi}\left(\theta_{j}-\frac{1}{2} \sin 2 \theta_{j}\right)\left(1-\tilde{\alpha}_{j}\right)+K_{j} \tilde{\alpha}_{j}
$$

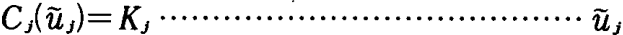

$S_{j}\left(\widetilde{u}_{j}\right)=\frac{-K_{j}}{\pi}\left(1-\tilde{\alpha}_{j}\right) \sin ^{2} \theta_{j} \ldots \ldots \ldots \ldots \cdots \cdots \tilde{u}_{j}>1$

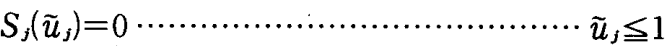

$\theta_{j}=\cos ^{-1}\left(1-\frac{2}{\widetilde{u}_{j}}\right) \cdots \cdots \cdots \cdots \cdots \cdots \cdots \cdots \cdots \cdots \cdots \tilde{u}_{j}>1$

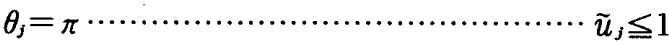

$\tilde{u}_{j}=\frac{X_{j}}{X_{y j}}=\frac{K_{j} X_{j}}{\tilde{Q}_{y j}} \quad\left(X_{y j}: j\right.$ 層の降伏変位 $)$

$\tilde{Q}_{y j}, \tilde{\alpha}_{j}$ : 確率変数 $Q_{y j}, \alpha_{j}$ のある任意の值 変位振偪 $X_{j}(\omega) e^{i \omega t}$ と (3-2) 式を(3-1) 式に代入す ると，周波数領域での釣合式は次式になる。

$$
\left[\boldsymbol{K}\left(\omega, \tilde{Q}_{y j}, \tilde{\alpha}_{j}, C_{j}\left(\tilde{u}_{j}\right), S_{j}\left(\tilde{u}_{j}\right), D_{j}\right)\right]|X|=\{Y\}
$$

ただし, $\{X\}:\left\{X_{1}(\omega), X_{2}(\omega), \cdots, X_{m}(\omega)\right\}^{T}$

$\{Y\}:-\left\{\sum_{k=1}^{m} m_{k}, \cdots, \sum_{k=j}^{m} m_{k}, \cdots, m_{n}\right\}^{T} \ddot{Y}(\omega)$

$\ddot{Y}(\omega): \ddot{y}(t)$ のフーリェ変換

$[\boldsymbol{K}]$ ：入力の $\omega$ 成分に対する振動系の剛性マト リックス

（3-3）式は複素関数を含むが線形方程式である。それ故, 調和入力の場合には，(3-3) 式を解くことが可能で, 一 般に調和入力 $\ddot{Y}(\omega) e^{i \omega t}$ に対する振動系の変位振幅 $X$, を求める問題になる。実際の地震波を対象とする場合は, 地震波は広带域の周波数特性を示すので， $X_{j}$ は周波数 成分ごとに異なり，一意的に定まらない。それ故，ここ では，(3-2）式に含まれる変位振幅 $\widetilde{u}_{j}$ を履歴振動系の 等価剛性と等価履歴減衰を推定するための一つのパラメ

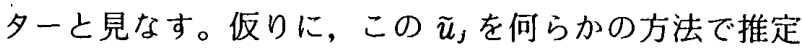
することができると仮定すれば, (3-3)式の剛性マトリッ クスの係数は既知になるから，一般の地震入力波に対し ても（3-3）式は容易に解ける。そのとき，広帯域を有 する地震波を受ける履歴振動系の周波数応答は，入力波 
に含まれるそれぞれの周波数成分に対する解の重ね合わ せから得られる。 $\tilde{u}_{j}$ の求め方については次項で述べる。

\section{§4. エネルギー入力の周波数領域での表現式}

この項では，まず始めに履歴振動系へのエネルギー入 力を周波数領域で表現する。地震波による $\mathrm{j}$ 層へのエネ ルギー入力は時間領域において次式で表される。

$$
W_{j}(t)=-\sum_{i=j}^{n} m_{i} \cdot \int_{0}^{t} \ddot{y}(\tau) \dot{X}_{j}(\tau) d \tau
$$

\section{ただし， $t:$ 入力継続時間}

(3-3) 式から得られる速度応答は, 周波数領域の式で あるから(4-1)式を周波数領域へ変換すると都合がよい。 (3-2) 式に含まれるパラメター $\tilde{Q}_{y j}, \tilde{\alpha}_{j}$ は確定值である が, このパラメターを確率変数 $Q_{y}, \alpha_{s}$ で置換し, Parsevels の公式を用いると，(4-1) 式は次式にな $3^{16) .14)}$ 。

$$
\begin{array}{r}
W_{j}(t)=-\frac{1}{2 \pi} \sum_{i=j}^{n} m_{i} \cdot \operatorname{Real}\left\{\int _ { - \infty } ^ { \infty } \ddot { Y } ( \omega ) \dot { X } _ { J } ^ { * } \left(\omega, Q_{y 1},\right.\right. \\
\left.\left.\alpha_{1}, \cdots, \tilde{u}_{j}\right) d \omega\right\} \cdots \cdots \cdots \cdots \cdots \cdots \cdots(4-2)
\end{array}
$$

ただし，*：共役複素数

(4-2）式からエネルギー入力は確率変数を含む閉じた関 数式で定義でき，その統計量は確率論的処理によって得

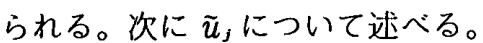

確率変数を含む Bilinear モデルをもつ履歴振動系の エネルギー応答の変動は, 確率変数の平均值によって代 表された Bilinear モデルをもつ振動系が地震波を受け たときのエネルギー入力值からの偏差によって評価され ると仮定する。前述のように，調和入力の場合は，(3-2) 式の $\widetilde{u}_{j}$ は変位振幅を表すが地震波入力の場合は明確な 意味を持たない。そこで，本論では，First order 近似 に従い，(4-2）式に含まれる確率変数を平均值で代表さ せた（4-3）式の值がある特別な值を持つように決める ことにする。

$$
\begin{array}{r}
\bar{W}_{\jmath}(t)=-\frac{1}{2 \pi} \sum_{i=j}^{n} m_{i} \cdot \operatorname{Real}\left\{\int _ { - \infty } ^ { \infty } \ddot { Y } ( \omega ) \dot { X } _ { j } ^ { * } \left(\omega, \bar{Q}_{y 1},\right.\right. \\
\left.\left.\bar{\alpha}_{1}, \cdots, \tilde{u}_{\jmath}\right) d \omega\right\} \cdots \cdots \cdots \cdots \cdots \cdots \cdots \cdots(4-3)
\end{array}
$$

ただし, $\bar{Q}_{y j}, \bar{\alpha}_{j}, \cdots: Q_{y j}, \alpha_{j}, \cdots$ の平均値

ここで，平均值で代表された Bilinear モデルを持つ振 動系のエネルギー入力の值を得るために, 時間領域の数 值計算が一度だけ許されるとし，この值を $\bar{W}_{j s}$ とすれ ば， $\tilde{u}_{j}$ は， $\bar{W}_{j s}$ と (4-3) 式を等置したエネルギーバラ ンス式から得られる。この場合, 収斂計算が必要で本論 では次式を用いた。

$$
\left|\bar{W}_{s s}-\bar{W}_{j}\right| \leqq 0.005 \bar{Q}_{y j}^{2} K_{j}
$$

このような考え方は，(3-2) 式の $\tilde{u}_{j}$ を，エネルギー入 力の First Order 期待值が $\bar{W}_{s s}$ に等しくなるような等 価な線形振動系の剛性と履歴减衰を評価するための一つ
のパラメターと見なすことに相当する。(4-4) 式の計算 から得られる $\tilde{u}_{j}$ を(3-2) 式に代入すると次式になる。

$$
X_{j}=\widetilde{u}_{j}^{0} \frac{\bar{Q}_{y j}}{K_{j}}
$$

ただし， $\widetilde{u}_{j}^{0}: \widetilde{u}_{j}$ の既知の值

そのとき，(3-2) 式の $\theta_{j}$ は次のように更新される。

$$
\theta_{j}=\cos ^{-1}\left(1-\frac{2}{\tilde{u}_{j}^{0} \frac{Q_{y j}}{\bar{Q}_{y j}}}\right)
$$

結局，(3-3) 式は確率変数のみを含む閉じた形の関数式 になる。(4-6) 式において,

$$
\tilde{u}_{j}^{0} \frac{Q_{y j}}{\bar{Q}_{y j}} \leqq 1
$$

の場合には弾性応答になる。

\section{§5. エネルギー応答の統計量}

(4-1) 式は, 振動系への全体のエネルギー入力を表す。 一般に，このエネルギー入力は次の 3 つに分けられる。

$$
\tilde{W}_{j}=\tilde{W}_{e j}+\tilde{W}_{d j}+\tilde{W}_{\rho j}
$$

ただし， $\tilde{W}_{e j}: j$ 層の弾性振動によって吸収される無次 元エネルギー入力

$\tilde{W}_{d j}: j$ 層の粘性減衰によって吸収される無次 元エネルギー入力

$\tilde{W}_{\rho j}: j$ 層の累積塑性変形によって吸収される 無次元エネルギー入力

(5-1) 式の 3 つのエネルギー量はすべて確率湾数であ り, $Q_{y_{j}}^{2} K_{j}$ によって無次元化される。 $\tilde{W}_{j}$ の統計量は (4-2) 式から次式になる。

$$
\begin{aligned}
E\left[\tilde{W}_{j}\right]= & -\frac{K_{j}}{2 \pi} \sum_{i=j}^{n} m_{i} \cdot \int_{-\infty}^{\infty} \cdots \int \operatorname{Real}\left\{\int_{-\infty}^{\infty}\right. \\
& \left.\cdot \ddot{Y}(\omega) \dot{X}_{j}^{*}\left(\omega, Q_{y 1}, \alpha_{1}, \cdots, \tilde{u}_{j}^{0}\right) d \omega\right\} \\
& \cdot \frac{1}{Q_{y j}^{2}} \cdot p\left(Q_{y 1}, \alpha_{1}, \cdots\right) d Q_{y 1} d \alpha_{1} \cdots \\
E\left[\tilde{W}_{j}^{2}\right]= & \frac{K_{j}^{2}}{4 \pi^{2}}\left\{\sum_{i=j}^{n} m_{i}\right]^{2} \cdot \int_{-\infty}^{\infty} \cdots \int \operatorname{Real}\left\{\int_{-\infty}^{\infty}\right. \\
& \left.\cdot \ddot{Y}(\omega) \dot{X}_{j}^{*}\left(\omega, Q_{y 1}, \alpha_{1}, \cdots, \tilde{u}_{j}\right) d \omega\right|^{2} \\
& \cdot \frac{1}{Q_{y j}^{4}} \cdot p\left(Q_{y 1}, \alpha_{1}, \cdots\right) d Q_{y 1} d \alpha_{1} \cdots \\
V\left[\tilde{W}_{j}\right]= & E\left[\tilde{W}_{j}^{2}\right]-E^{2}\left[\tilde{W}_{j}\right]
\end{aligned}
$$

ただし， $p\left(Q_{y_{1}}, \alpha_{1}, \cdots\right): Q_{y_{1}}, \alpha_{1}, \cdots$ の結合確率密度関 数

$$
E\left[X^{2}\right], V[x]: x \text { の } 2 \text { 乗平均, 分散 }
$$

$\tilde{W}_{j}$ の統計量は (5-2) 式から確率論的に正確に得られる。 しかしながら， $\tilde{W}_{p j}$ の統計量を正確に得るこよは極端 に難しい。それ故，次のような近似的方法を考えること にする。(5-1) 式の両辺の平均值は次式になる。 


$$
E\left[\tilde{W}_{j}\right]=E\left[\tilde{W}_{e j}\right]+E\left[\tilde{W}_{d j}\right]+E\left[\tilde{W}_{\rho j}\right] \cdots \cdot(5-3)
$$

（5-1）式と（5-3）式の差の 2 乗平均は近似的に次式に なる。

$$
V\left[\tilde{W}_{J}\right] \simeq V\left[\tilde{W}_{e j}\right]+V\left[\tilde{W}_{d j}\right]+V\left[\tilde{W}_{\rho j}\right] \cdots(5-4)
$$

(5-4) 式は, ランダム変数 $\tilde{W}_{e j}-E\left[\tilde{W}_{e j}\right], \tilde{W}_{d j}-E$ $\left[\tilde{W}_{d j}\right]$ さらに $\tilde{W}_{p j}-E\left[\tilde{W}_{p j}\right]$ の相関関数は十分小さい之 いう仮定を含んでいる。(5-3) 式と (5-4) 式の左辺の 統計量は既知であるから，右辺の $\tilde{W}_{p j}$ の統計量を近似 的に次式から推定することが可能であると仮定する。

$$
\begin{aligned}
& E\left[\tilde{W}_{\rho j}\right]=r_{j} E\left[\tilde{W}_{j}\right] \\
& r_{j}=\frac{\tilde{W}_{p j s}}{\tilde{W}_{s s}} .
\end{aligned}
$$

ただし， $\tilde{W}_{s s}, \tilde{W}_{p s s}$ : 平均值で代表された Bilinear モデ ルをもつ振動系への全体のエネルギー入力と累積塑性変 形によるエネルギー入力で時間領域の数值計算から得ら れる。

(5-4) 式の $V\left[\tilde{W}_{j}\right] と V\left[\tilde{W}_{p j}\right]$ の比は数值計算から得 られない。それ故, ここでは, (5-3) 式の $E\left[\tilde{W}_{p j}\right]$ 人 の配分を表す (5-5) 式の類推から，(5-4) 式の配分に 対しても (5-5) 式の比が有効であると仮定する。

$$
V\left[\tilde{W}_{p j}\right]=r_{j} V\left[\tilde{W}_{j}\right]
$$

(5-5) 式之 (5-6) 式の妥当性については, モンテカル ロシミュレーションの結果との比較から検討する。

\section{§6. エネルギー応答の First Order 近似}

（5-2）式に示したエネルギー入力の統計量は正確な表 現式である。この式は多重積分を含むので, 多自由度系 に対して（5-2）式を正確に計算することは非常に困難 である。それ故, 簡単な近似計算手法が要求されるだろ う。(5-2) 式は確率変数を含む関数とみなすことができ るから，テーラー展開による近似手法を用いることが可 能である。(5-2) 式の First Order 近似は次のようにな る。

$$
\begin{aligned}
E\left[W_{j}\right] \simeq & -\frac{1}{2 \pi} \sum_{i=j}^{n} m_{i} \cdot \Gamma_{j} \\
V\left[W_{j}\right] \simeq & \frac{1}{4 \pi^{2}} \cdot\left\{\sum_{i=j}^{n} m_{i}\right\}^{2} \cdot \sum_{l=1}^{2 n} \sum_{k=1}^{2 n} \frac{\partial \Gamma_{j}}{\partial Z_{l}} \\
& \cdot \frac{\partial \Gamma_{j}}{\partial Z_{k}} \operatorname{cov}\left[Z_{l}, Z_{k}\right]
\end{aligned}
$$

ただし，

$$
\begin{aligned}
& \Gamma_{j}=\operatorname{Real}\left\{\int_{-\infty}^{\infty} \ddot{Y}(\omega) \dot{X}_{j}^{*}\left(\omega, \bar{Z}_{1}, \bar{Z}_{2}, \cdots, \bar{u}_{j}^{0}\right) d \omega\right\} \\
& \bar{Z}_{1}=\bar{Q}_{y 1}, \bar{Z}_{2}=\bar{\alpha}_{1}, \cdots \\
& \operatorname{COV}\left[Z_{l}, Z_{k}\right]: Z_{l} \text { の共分散関数 }
\end{aligned}
$$$$
\text { (Covariance function) }
$$

(6-1) 式の計算には速度成分 $\dot{X}_{j}^{*}$ の $Z_{l}$ に関する微分 值が必要である。(3-3) 式を $Z_{\imath}$ について微分し, さら に（3-3）式を用いると, $\dot{X}_{j}^{*}$ の微分は次のように得ら
れる。

$$
\left.\frac{\partial|\dot{X}|^{*}}{\partial Z_{k}}=\operatorname{Conjg}\left[-i \omega[K]^{-1} \frac{\partial[K]}{\partial Z_{k}}[K]^{-1} \mid Y\right\}\right]
$$

(6-1) 式と (6-2) 式から全体のエネルギー入力の統計 量の First Order 近似が得られる。:First Order 近似の 無次元エネルギー入力 $\tilde{W}_{j}$ の統計量は次のようになる。

$$
\begin{aligned}
& E\left[\tilde{W}_{j}\right]=\frac{E\left[W_{j}\right] K_{j}}{E^{2}\left[Q_{y_{j}}\right]} \\
& \text { C.o.V. }\left[\tilde{W}_{j}\right]=\sqrt{\text { C.O.V. }\left[W_{j}\right]+4 \cdot \text { C.O.V. }\left[Q_{y j}\right]}
\end{aligned}
$$

さらに, $\tilde{W}_{p j}$ の統計量は次式になる。

$$
\left.\begin{array}{l}
E\left[\tilde{W}_{p j}\right]=r_{J} E\left[\tilde{W}_{. j}\right] \\
\text { C.o.V. }\left[\tilde{W}_{p j}\right]=\frac{1}{\sqrt{r_{j}}} \text { C.o.V. }\left[\tilde{W}_{J}\right]
\end{array}\right\} .
$$

§7. 解析結果とモンテカルロシミュレ゙ーションの結果 の比較

これまで，不確定要素を含むBilinear モデルの振動 系が地震波を受けたときのエネルギ一応答を解析的に評 価する方法を論じた。ここでは，シミュレーションの結 果との比較を行い，本論で用いた近似方法および仮定等 に関する検討を行う。

まず，(5-2）式で表される解と（6-1）式で表される First Order による近似解の比較を行う。解析モデルは

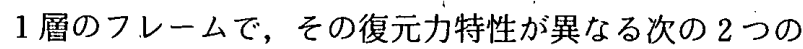
モデルである。

(1)，モデルA（復元力特性：Fig. 5)

$$
E\left[\dot{Q}_{y}\right]=36.6 \mathrm{t} \quad \text { C.O.V. }\left[Q_{y}\right]=0.069
$$

剛性 $K=20.5 \mathrm{t} / \mathrm{cm}$ ，減衰常数 $h=2 \%$

周期 $T=0.4 \mathrm{sec}, 0.5 \mathrm{sec}$

（2）モデル.B（復元力特性：Fig. 6)

$Q_{y}, K, h, T$ はモデル A と同じ

$$
E[\ddot{\alpha}]=0.0095 \quad \text { ' C.0.V. }[\alpha]=0.149^{\circ}
$$

$\rho\left(Q_{y}, \alpha\right)=0(\rho(X, Y): X$ とYの相関係数 $)$

入力地震動 : El Centro Earthquake (Max. $\ddot{y}=346$ gal, duration $=20 \mathrm{sec}$ )

結果を表- 1 と 2 に示した。解法（1）は（5-2）式に

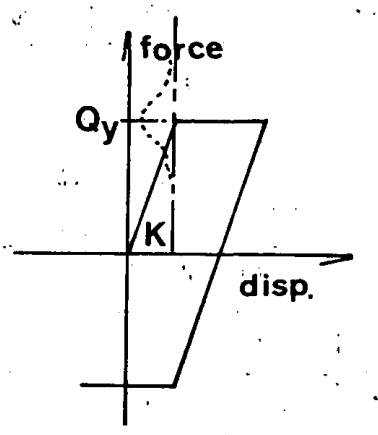

Fig. 5 Restoring Force Model ( $Q_{y}:$ Random Variable) 
よる解であり, 解法（2）は（6-1）式による First Order 近似である。シミュレーションの数は 100 である。

解法（1）はシミュレーションの結果と非常によい対 応を示しているが，多重積分の複雑さおよび計算時間等
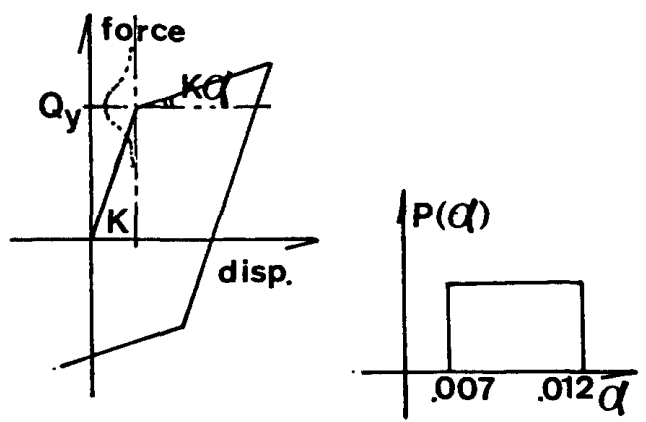

Fig. 6 Restoring Force Model ( $Q_{y}, \alpha$ : Random Variable)

表-1 Comparision between analytical results and Monte Carlo Simulation (モデル A)

\begin{tabular}{|l|l|l|l|l|}
\hline & \multicolumn{2}{|c|}{$\widetilde{W}_{1}$} & \multicolumn{2}{c|}{$\widetilde{w}_{1}$} \\
\hline & mean & c.0.v. & mean & c.o.v. \\
\hline Method (1) & 6.37 & 0.180 & 3.79 & 0.233 \\
\hline Method (2) & 6.22 & 0.143 & 3.70 & 0.186 \\
\hline Simulation & 6.36 & 0.157 & 3.81 & 0.205 \\
\hline
\end{tabular}

$(T=0.4 \mathrm{sec})$

\begin{tabular}{|l|c|l|l|l|}
\hline & \multicolumn{2}{|c|}{$\widetilde{W}_{1}$} & \multicolumn{2}{c|}{$\widetilde{W}_{1}$} \\
\hline & mean & c.0.v & mean & c.0.v. \\
\hline Method (1) & 17.88 & 0.175 & 14.15 & 0.197 \\
\hline Methoh (2) & 17.47 & 0.141 & 13.83 & 0.158 \\
\hline Simulaton & 18.07 & 0.185 & 14.35 & 0.197 \\
\hline
\end{tabular}

$(T=0.5 \mathrm{sec})$

表一2 Comparision between analytical results and Monte Carlo Simulation (モデル B)

\begin{tabular}{|l|l|l|l|l|}
\hline & \multicolumn{2}{|c|}{$\widetilde{W}_{1}$} & \multicolumn{2}{c|}{$\widetilde{w}_{p_{1}}$} \\
\hline & mean & c.o.v. & mean & c.0.v. \\
\hline Method (1) & 6.39 & 0.181 & 3.78 & 0.235 \\
\hline Method (2) & 6.23 & 0.143 & 3.68 & 0.186 \\
\hline sigulation & 6.36 & 0.157 & 3.81 & 0.204 \\
\hline
\end{tabular}

$(T=0.4 s \in c)$

\begin{tabular}{|l|c|l|l|l|}
\hline & \multicolumn{2}{|c|}{$\widetilde{W}_{1}$} & \multicolumn{2}{c|}{$\widetilde{W}_{p 1}$} \\
\hline & mean & c.o.v. & mean & c.o.v. \\
\hline Method(1) & 17.87 & 0.176 & 14.11 & 0.198 \\
\hline Method(2) & 17.49 & 0.140 & 13.81 & 0.158 \\
\hline Simulation & 17.95 & 0.186 & 14.23 & 0.199 \\
\hline
\end{tabular}

$(T=0.5 \mathrm{sec})$
を考えると，実用的には 1 質点系に限定されるだろう。 解法（2）は平均値で約 $3 \%$, 変動係数で約 $20 \%$ ほど 小さな值を示している。解法（2）は変動係数がかなり 小さな値になっているが，計算時間と計算の容易さ等を 考えると工学的に許される方法であると思われる。平均 值で代表された構造系に対して，一度時刻歴の数值計算 を実行しているため，特に，平均值はシミュレーション の結果とよい対応を示している。

(5-2) 式による計算結果から，地震波による棈造物系 への全体のエネルギー入力は，(3-2）式の履歴減衰モデ ルを有する場合，地震波に含まれている周波数成分とそ の加速度振幅を持つ調和入力を受けたときの構造物系へ のエネルギー入力の各々の值を重㸚合わせることによっ て近似的に得られることを示している。

次に（5-6）式で用いた仮定の妥当性について述べる。

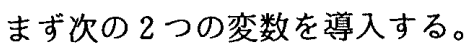

$$
\begin{aligned}
& r=\frac{\sum_{j=1}^{m} \tilde{W}_{p 1 s j} / m}{\sum_{j=1}^{m} \tilde{W}_{1 s j} / m} \\
& \tilde{r}=\frac{\sum_{j=1}^{m}\left(\tilde{W}_{\rho 1 s j}-\sum_{j=1}^{m} \tilde{W}_{\rho 1 s t} / m\right)^{2} / m}{\sum_{j=1}^{m}\left(\tilde{W}_{1 s j}-\sum_{j=1}^{m} \tilde{W}_{1 s i} / m\right)^{2} / m}
\end{aligned}
$$

ただし, $m:$ サンプルの数 $(100)$

$\tilde{W}_{1 s s}, \tilde{W}_{\rho 1 s s}$ : シミュレーションから得られる全体のエ ネルギー入力と累積塑性変形によるエネ ルギー入力

Fig.7は $r$ に対する $\tilde{r}$ の比を図示した。図中の $\Delta$ 印は C.O.V. $\left(Q_{y}\right)=0.069$ の結果を表し，○印は C.O.V. $\left(Q_{y}\right)$ $=0.138$ の場合の結果を表している。 $Q_{\boldsymbol{y}}$ の変動係数が 小さいときの值に比べて, 変動係数が大きいときの值が 平均的に多少 1 に近い值を示しているが，これは， $Q_{y}$ の変動が大きいほど (5-1) 式の右辺のそれぞれの項の 相関関係が小さくなるためと思われる。このようなシ ミュレーションの結果から（5-6）式で用いた仮定は工 学的に妥当であると思われる。表一 1 と表一 2 の比較か ら降伏後の剛性の変動の影響は十分小さいようである。 Fig. 8 はモデル A の $\tilde{W}_{1}, \tilde{W}_{p 1}$ の密度関数を比較した。 図中の実線は (5-2) 式から，また破線は（6-1）式から

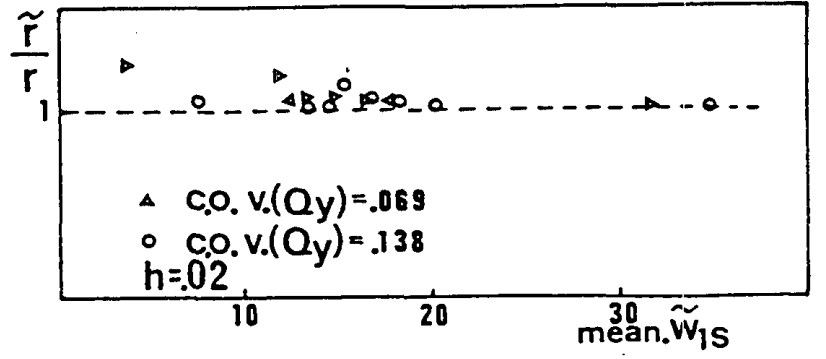

Fig. 7 Relationship Between $\frac{\tilde{r}}{r}$ and mean. $\tilde{W}_{1 s}$ 

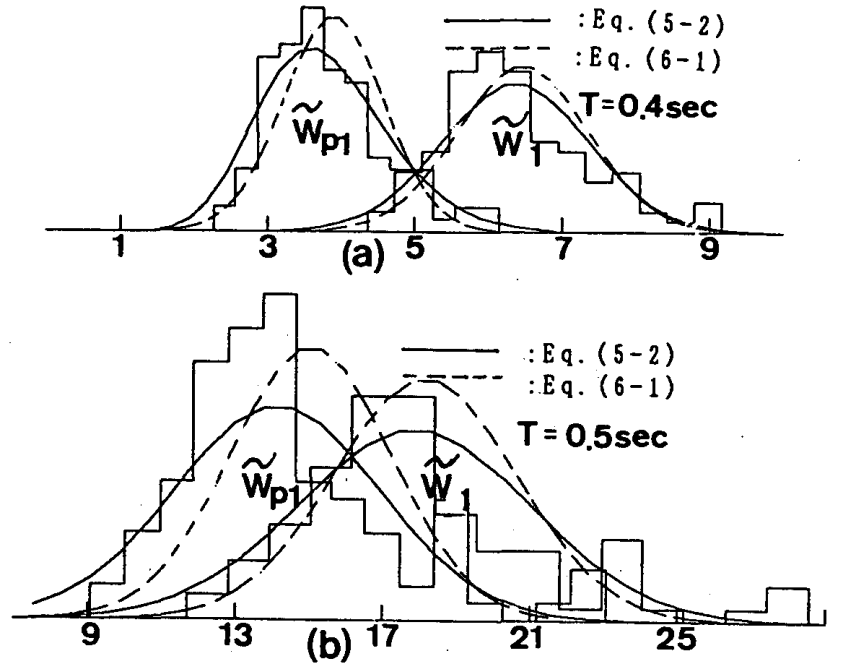

Fig. 8 Probability density function

求めた平均と分散を用いてガンマ分布で近似した。

本論で注目している履歴振動系へのエネルギー入力 は，(4-1）式で示したように入力波と速度応答の積から 得られる。この速度応答が履歴系特有な振動中心の移動

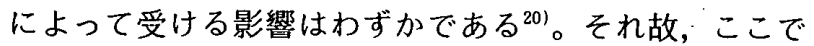
は塑性変形による振動中心の移動を無視した等価履歴减 衰による線形化法により，エネルギー入力の統計量を評 価したが, シミュレーションの結果との比較から，おお むね満足できるものと思われる。ここで述べた解析手法 は一種の等価線形化法である。そのため，入カレベルに 比べて，降伏強度がかなり小さいと塑性変形が非常に大 きくなり，等価な履歴減衰と剛性を (4-4) 式から決め ることができないが, 周期 0.2 SEC で勒性率 8 9, 周 期 0.5 SEC で勒性率 6 7 程度の入力レベルに対して計 算が可能である。

\section{§8. 不確定復元力特性を有する履歴振動系の安全の確 率}

これまで，不確定復元力特性を有する履歴振動系への エネルギー応答の統計量を解析的に評価する手法につい て論じた。材料の予期しない低い降伏応力は，大きな塑 性変位を引き起こし, 構造物の安全性に重大な影響を与
えると思われるので，その影響の度合いを定量的に評価 することは重要である。

本論では構造物の信頼性に対する判定規範として次式 を用いる。

$$
R_{j}(t)=P\left[\tilde{W}_{R}>\tilde{W}_{p j}(t)\right]
$$

ただし， $R_{J}(t)$ : 応答時間 $(0, t)$ における $j$ 層の安 全の確率

$\tilde{W}_{R}:$ 累積塑性変形によって吸収される許容 無次元エネルギー入力で確率変数

このような問題は，一般に初通過問題として知られ，正 解を求めることは非常に困難なため, 近似解法に関する 研究が多くなされている(13),19)。しかしながら，これらの 研究は，不確定入力に対する確定振動系の安全の確率に ついて論じたもので，確定入力に対する不確定振動系の 安全の確率について述べたものではない。この項では, 不確定性復元力特性を有する履歴振動系が確定入力波を 受けたときの安全の確率について述べる。

確率変数を含む不確定振動系の安全の確率は, 確率変 数の関数として評価されると思われるので，まず次のよ うな確率変数を条件付にした危険率を定義すると大変都 合がよい15)。

$$
\begin{aligned}
\lambda_{f}\left(\tau \mid Q_{y 1}, \alpha_{1}, \cdots\right)= & -\frac{1}{R_{f}\left(\tau \mid Q_{y 1}, \alpha_{1}, \cdots\right)} \\
& \cdot \frac{\partial R\left(\tau \mid Q_{y 1}, \alpha_{1}, \cdots\right)}{\partial \tau}
\end{aligned}
$$

ただし, $\lambda_{j}\left(\tau \mid Q_{y_{1}}, \alpha_{1}, \cdots\right)$ :危険率と言われる変数で, 確率変数をある値に固定したときに，応答時間 $\tau$ で安 全，すなわち振動系は残存しているという条件下で引続 く単位応答時間に振動系に生じる $\tilde{W}_{p,}$ が $\tilde{W}_{R}$ を超える 平均的回数

もし，危険率がある程度小さければ，応答時間 $(0, t)$ における安全の確率は次式になる。

$$
R_{j}(t) \simeq e^{-\int_{0}^{t} \lambda_{v}(\eta) d \tau}
$$

ただし, $\lambda_{f}(\tau)=E\left[\cdots E\left[\lambda_{j}(\tau) \mid Q_{y_{1}}, \alpha_{1}, \cdots\right]\right]$

（8-3）式の危険率の期待值は次のように求められる。 発見的仮定に基づく(8-2)式の期待値は次式になる15)。

$$
\lambda_{j}(\tau)=-\frac{\int_{-\infty}^{\infty} \cdots \int \frac{\partial R_{j}\left(\tau \mid Q_{y 1}, \alpha_{1}, \cdots\right)}{\partial \tau} P\left(Q_{y 1}, \alpha_{1}, \cdots\right) d Q_{y 1} d \alpha_{1}, \cdots}{\int_{-\infty}^{\infty} \cdots \int R_{j}\left(\tau \mid Q_{y 1}, \alpha_{1}, \cdots\right) P\left(Q_{y 1}, \alpha_{1}, \cdots\right) d Q_{y 1} d \alpha_{1}, \cdots}
$$

(8-2) 式を（8-4）式に代入すると次式を得る。

$$
\lambda_{f}(\tau)=\frac{\int_{-\infty}^{\infty} \cdots \int \lambda_{f}\left(\tau \mid Q_{y 1}, \alpha_{1}, \cdots\right) R_{f}\left(\tau \mid Q_{y 1}, \alpha_{1}, \cdots\right) P\left(Q_{y 1}, \alpha_{1}, \cdots\right) d Q_{y 1} d \alpha_{1}, \cdots}{: \int_{-\infty}^{\infty} \cdots \int R_{J}\left(\tau \mid Q_{y 1}, \alpha_{1}, \cdots\right) P\left(Q_{y 1}, \alpha_{1}, \cdots\right) d Q_{y_{1}} d \alpha_{1}, \cdots}
$$

(8-5) 式において，Bayes の定理を用いると次式が成立する。 


$$
\frac{R_{j}\left(\tau \mid Q_{y 1}, \alpha_{1}, \cdots\right) P\left(Q_{y 1}, \alpha_{1}, \cdots\right)}{\int_{-\infty}^{\infty} \cdots \int R_{j}\left(\tau \mid Q_{y 1}, \alpha_{1}, \cdots\right) p\left(Q_{y 1}, \alpha_{1}, \cdots\right) d Q_{y 1} d \alpha_{1}, \cdots}=p\left(Q_{y 1}, \alpha_{1}, \cdots \mid \tau\right)
$$

ただし, $P\left(Q_{y 1}, \alpha_{1}, \cdots \mid \tau\right): \tau$ 時間後の残存構造物の $Q_{y 1}, \alpha_{1}, \cdots$ の結合確率密度関数

結局, 不確定性を有する履歴振動系の安全の確率は次式 になる。

$$
R_{J}(t)=e^{-\int_{0}^{t} \lambda(r) d \tau}
$$

ただし，

$$
\begin{aligned}
\lambda_{f}(\tau)= & \int_{-\infty}^{\infty} \cdots \int \lambda_{j}\left(\tau \mid Q_{y 1}, \alpha_{1}, \cdots\right) P\left(Q_{y 1}, \alpha_{1}, \cdots\right) \\
& d Q_{y 1} d \alpha_{1} \cdots
\end{aligned}
$$

(8-7)式の安全の確率はほぼ正解に近い表現式であるが, (8-7) 式の危険率を正しく評価することは大変難しい。 それ故，次のような近似を行う。(8-5) 式の分母は応答 時間 $(0, \tau)$ における安全の確率であるが，応答履歴を 無視した応答時間 $\tau$ における安全の確率で近似的に評 価されるものと仮定すれば， $R_{j}\left(\tau \mid Q_{y_{1}}, \alpha_{1}, \cdots\right)$ は次式に なる。

$$
\begin{array}{r}
R_{J}\left(\tau \mid Q_{y_{1}}, \alpha_{1}, \cdots\right)=1-\int_{0}^{\infty} F_{\tilde{W}_{R}}(W) P_{W_{p j}}\left(W, \tau \mid Q_{y_{1}},\right. \\
\left.\alpha_{1}, \cdots\right) d W \cdots \cdots \cdots \cdots \cdots(8-8)
\end{array}
$$

ただし， $F_{\widetilde{W}_{R}}(W): \tilde{W}_{R}$ の確率分布関数（正規分布を仮定 する)

$P_{\tilde{W}_{p j}}\left(W, \tau \mid Q_{y 1}, \cdots\right)$ : 確率変数 $Q_{y 1}, \cdots$ がある值をとると いう条件下での確率密度関数

このような近似方法はマルコフ近似に近い考え方であ る。確率変数 $Q_{y 1}, \cdots$ をある値に固定したときの $\tilde{W}_{p j}$ は応答時間 $\tau$ において確定値になるから， $\tilde{W}_{p j}$ の密度 関数は次のようなデル夕関数になる。

$$
P_{\tilde{W}_{p j}}\left(W, \tau \mid Q_{y 1}, \alpha_{1}, \cdots\right)=\delta\left(W(\tau)-\tilde{W}_{p j}^{0}\right) \cdots(8-9)
$$

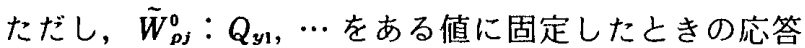

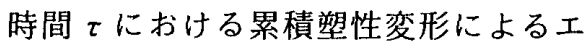
ネルギー入力で確定值

(8-9) 式を (8-8) 式に代入すると, 次式

$$
R_{j}\left(\tau \mid Q_{y 1}, \alpha_{1}, \cdots\right)=1-F_{\tilde{w}_{h}}\left(\tilde{W}_{p j}^{0}\right)
$$

になる。さらに（8-10) 式を(8-5) 式に代入し，さら に（8－2）式を用いると, 結局, 不確定性を有する履歴 振動系の安全の確率は次式になる。

$$
R_{j}(t)=e^{-\tilde{n}_{j}(t)}
$$

ただし

$$
\tilde{\lambda}_{j}(t)=\frac{\int_{-\infty}^{\infty} \cdots \int F_{\tilde{W}_{R}}\left(W_{p s}^{0}, t\right) P\left(Q_{y_{1}}, \alpha_{1}, \cdots\right) d Q_{y 1} d \alpha_{1} \cdots}{1-\int_{-\infty}^{\infty} \cdots \int F_{\tilde{w}_{R}}\left(W_{p j}^{0}, t\right) P\left(Q_{y 1}, \alpha_{1}, \cdots\right) d Q_{y 1} d \alpha_{1} \cdots}
$$

Kuwamura，Galambos は，構造物が建設される地域 に予想される構造物系への最大エネルギー入力の密度関 数を推定し，本論と同様な信頼性に関する判定規範を用 いたときの安全の確率を近似的に評価した ${ }^{171}$ 。本論の (8-11) 式は, $\tilde{W}_{p j}$ の密度関数を推定することなく,
直接 $\tilde{W}_{R}$ の分布関数から推定することができるという利 点がある。また, 入力波の不確定性による構造物系への エネルギー入力の変動がある場合も，(8-11) 式の $\tilde{W}_{p s}^{0}$ を入力波の不確定性の影響を含んだパラメーターと見な すことによって, 同様に評価することが可能ですると思 われる。

\section{§9. 解析結果の考察}

この項では，First Order 近似による解法（2）を用 いて解析結果の考察を行う。解析モデルは次の4ケース である。

（1） Case S-1（1 層骨組, 復元力特性：Fig.6)

$m_{1}=0.1 \mathrm{tsec}^{2} / \mathrm{cm}, \quad h=0.02$

$E\left[\alpha_{1}\right]=0.0095 \quad$ C.O.V. $\left[\alpha_{1}\right]=0.149$

$T=0.1 \mathrm{sec}, 0.2 \mathrm{sec}$ の場合

$E\left[Q_{y_{1}}\right]=36.4 \mathrm{t} \quad$ C.O.V. $\left[Q_{y_{1}}\right]=0.069$

$T=0.3 \mathrm{sec},-0.8 \mathrm{sec}$ の場合

$$
E\left[Q_{y_{1}}\right]=28.0 \mathrm{t} \quad \text { C.o.V. }\left[Q_{y_{1}}\right]=0.069
$$

（2） Case S-2（1 層骨組，復元力特性：Fig.6)

$$
E\left[Q_{y_{1}}\right]=36.4 \mathrm{t} \quad \text { C.O.V. }\left[Q_{y_{1}}\right]=0.138
$$

その他は Case S-1 と同じ

（3）Case T-1 (2 層骨組, 復元力特性 1, 2 層共 Fig. 6) $m_{1}=0.1 \mathrm{tsec}^{2} / \mathrm{cm}, \quad m_{2}=0.075 \mathrm{tsec}^{2} / \mathrm{cm}$

$K_{1}=K_{2}, \quad h=0.02$

$E\left[\alpha_{1}\right]=E\left[\alpha_{2}\right]=0.0095$, C.O.V. $\left[\alpha_{1}\right]=$ C.O.V.

$\left[\alpha_{2}\right]=0.149$

$\rho\left(\alpha_{1}, \alpha_{2}\right)=0$

$T=0.1 \mathrm{sec},-0.3 \mathrm{sec}$ の場合（1 次の固有周期）

$$
\begin{aligned}
& E\left[Q_{y_{1}}\right]=54.6 \mathrm{t} \quad E\left[Q_{y_{2}}\right]=33.6 \mathrm{t} \\
& \begin{array}{ll}
\text { C.O.V. }\left[Q_{y 1}\right]=0.069 & \text { C.O.V. }\left[Q_{y 2}\right]=0.069 \\
\rho\left(Q_{y 1}, Q_{y 2}\right)=0 &
\end{array}
\end{aligned}
$$

$T=0.4 \mathrm{sec},-0.8 \mathrm{sec}$ の場合（1 次の固有周期）

$$
\begin{aligned}
& E\left[Q_{y 1}\right]=36.4 \mathrm{t} \quad E\left[Q_{y_{2}}\right]=22.4 \mathrm{t} \\
& \begin{array}{ll}
\text { C.O.V. }\left[Q_{y 1}\right]=0.069 & \text { C.O.V. }\left[Q_{y_{2}}\right]=0.069 \\
\rho\left(Q_{y 1}, Q_{y 2}\right)=0 &
\end{array}
\end{aligned}
$$

（4）Case T-2(2 層骨組, 復元力特性 1, 2 層共 Fig. 6) $\rho\left(Q_{y_{1}}, Q_{y_{2}}\right)=0.7$ ，その他はCase T-1 と同じ

本諭で注目するエネルギ一応答量は構造物系への全体 のエネルギー入力と累積塑性変位によって吸収されるエ ネルギー入力 $\tilde{W}_{p j}$ の 2 つの確率量である。

Fig. 9 は Case S-1 の結果を図示した。解析値（解法 (2))はシミュレーションの結果と比べて, 表一1と 2 に示した結果同様に,平均值に対して平均的に約 $5 \%$ ， 変動係数に対しても平均的に約 $20 \%$ ほど小さい值を示 
している。Fig. 10 は Case S-2 の 結果である。降伏強度の変動係数が 大きいため解析結果とシミュレー ションの結果の差が大きくなり, 平 均値で約 $10 \%$ ，変動係数で $30 \%$ から $40 \%$ ほよ゙小さな值を示してい る。このように, First Order 近似 は降伏強度の変動係数が大きい場合 はかなり過小評価の結果をもたらす ので注意が必要である。Fig. 9 と Fig.10の結果から周期の短い場合 を除いて， $\tilde{W}_{p s}$.の変動係数は降伏 強度の変動係数の3 倍強になる。

Fig. 11 とFig. 12 は 2 質点系の 場合の結果である。Fig. 11 は 1 層 と2 層の降伏強度の相関係数が 0 で あるCase T-1の結果であ:り, Fig. 12 は 1 層と 2 層の降伏強度の 相関係数が 0.7 である Case T-2の 結果である。2 質点系の場合は，2 つのパラメター $\tilde{u}_{1}, \tilde{u}_{2}$ に対する (4-4) 式の収斂計算が必要になる。 1 層部分のエネルギー入力はある程 度大きいので 1 より大きい $\tilde{u}_{1}$ の值 を得ることができるが， 2 層部分の エネルギ二久力は小さく； $T=0.2$ $\sec$ と $T=0.3 \mathrm{sec}$ の場合を除いて, $\widetilde{u}_{2}$ は 1 より小さくなり正確な収斂 計算を奏行することができなかっ た。しかしながら，2 層部分のエネ ルギー入力は小さく, 結果はシミュ レーションの値に近いので, (4-4) 式から得られる值を近似的に解と見 なした。

これは本論で述べた解析手法の大 きな欠点であるが, 変数 $\tilde{u}_{j}$ の代わ りに重み関数 $f\left(\tilde{u}_{s}\right)$ を用いること によって解消されると思われる。

Fig.11とFig.12のそれぞれの 平均値は, $T=0.1 \mathrm{sec}$ を除いて平 均的に約 $5 \%$ ほよ゙小さく，また変 動係数も $20 \%$ から $100 \%$ 小さくな. る場合もあり，多質点系への First Order 近似の適用は注意が必要であ る。

1 層と.2 層のそれぞれの降伏強度の相関係数がある場 合とない場合の結果の差は，前記のように正確な収斂計 算を実行することができなかったために明らかにするこ

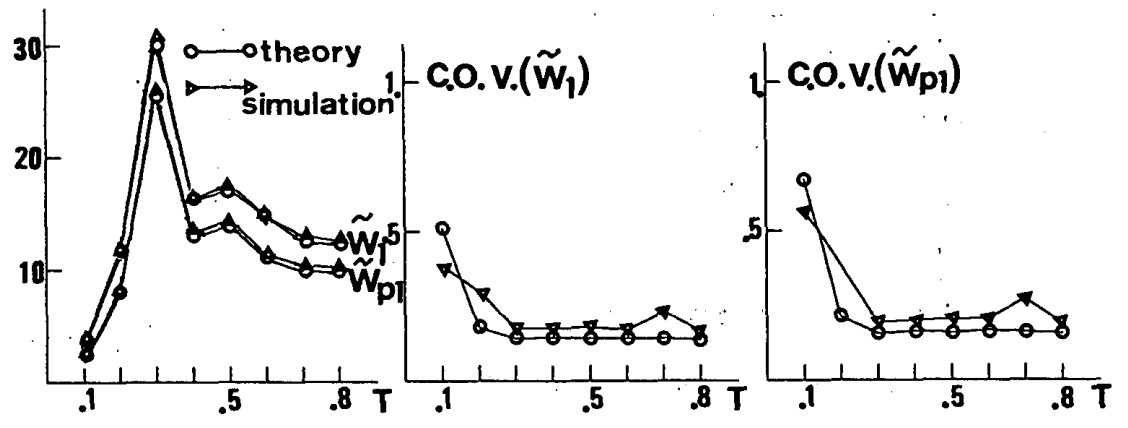

Fig. 9 Comparison with Simulation for Case S-1 (C.o.V. $\left(Q_{\mathbf{y}_{1}}\right)=0.069$, C.o.v. $\left.\left(a_{1}\right)=0.149\right)$

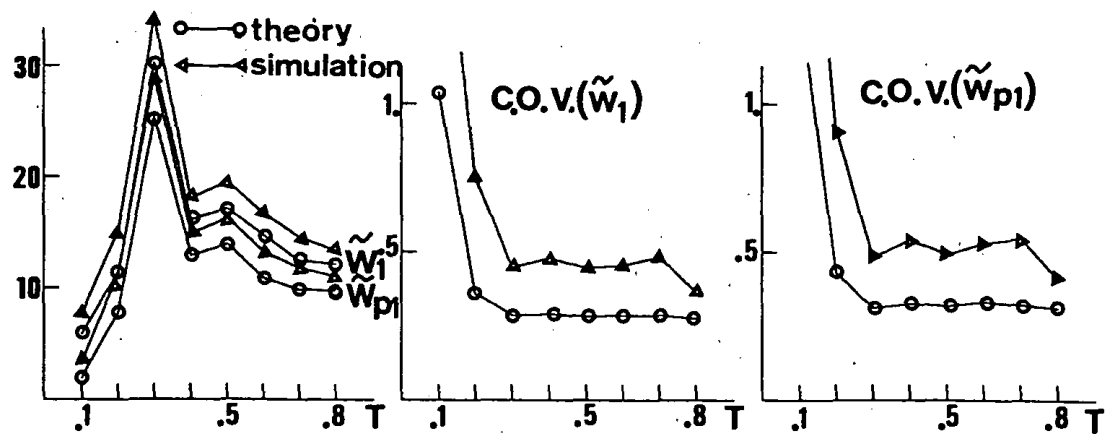

Fig. 10 Comparison with Simulation for Case S-2 (C.o.V. $\left(Q_{y 1}\right)=0.138$, C.o.V. $\left(a_{1}\right)=0.149$

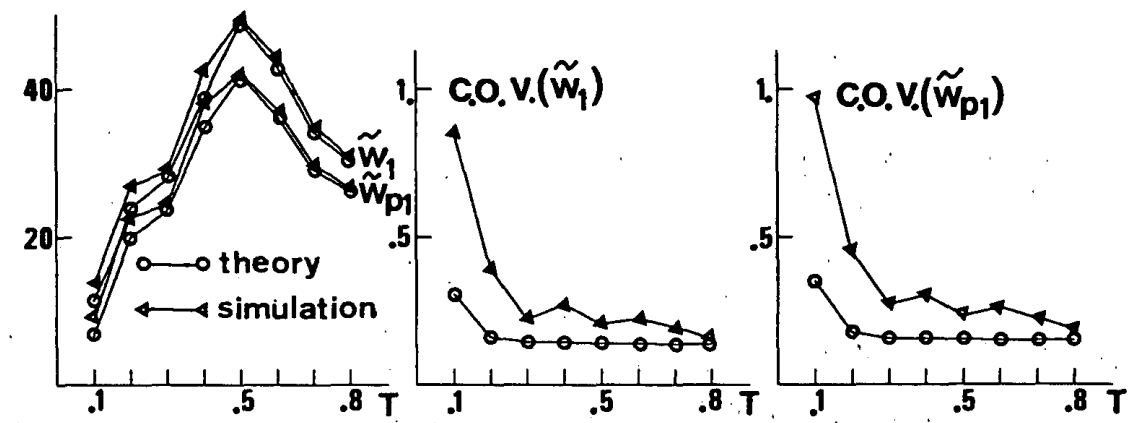

Fig. 11 Comparison with Simulation for Case T-1 (C.O.V. $\left(Q_{y_{1}}\right)=$ C.O.V. $\left(Q_{y_{2}}\right)=0.069, \quad \rho\left(Q_{y_{1}}, Q_{y z}\right)=$ 0., C.o.V. $\left(\alpha_{1}\right)=$ C.o.V. $\left(\alpha_{2}\right)=0.149, \rho\left(\alpha_{1}, \alpha_{2}\right)=0$. $)$

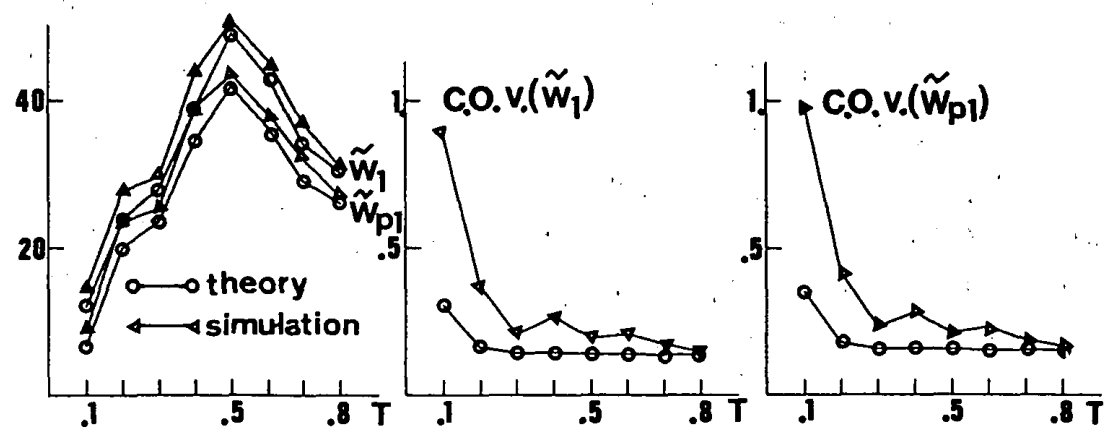

Fig. 12 Comparison with Simulation for Case T-2 (C.o.V. $\left(Q_{y 1}\right)=$ C.o.V. $\left(Q_{y_{2}}\right)=0.069, \quad \rho\left(Q_{y 1}, Q_{y_{2}}\right)=$ 0.7, C.o.V. $\left(\alpha_{1}\right)=$ C.0.V. $\left(\alpha_{2}\right)=0.149, \quad \rho\left(\alpha_{1}, \alpha_{2}\right)=$ 0.)

とができなかったが，シミュレーションの結果から考察 すると次のようになる。相関がある場合 $\left(\rho\left(Q_{y 1}, Q_{y_{2}}\right)\right.$ $=0.7) の \tilde{W}_{\rho 1}$ の平均值は, 相関がない場合 $\left(\rho\left(Q_{y 1}, Q_{y 2}\right)\right.$ 


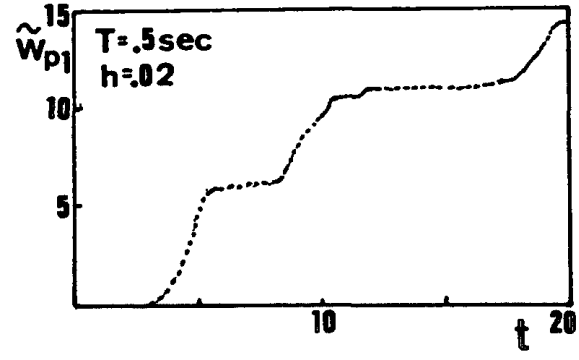

Fig. 13 Time History of $\tilde{W}_{p 1}$

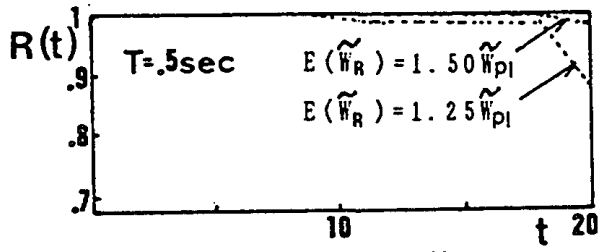

(a) C.o.v. $\left(\mathrm{O}_{y}\right)=c .0 . V \cdot\left(\tilde{W}_{R}\right)=0.009$

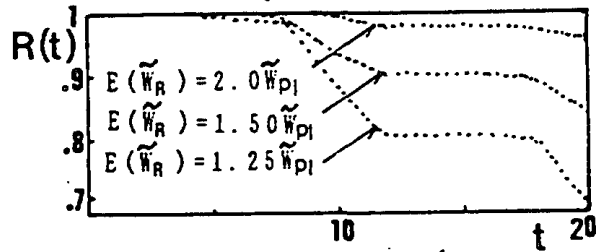

(b) $C .0 . V .\left(Q_{y}\right)=C .0 . V .\left(\tilde{H}_{R}\right)=0.138$

Fig. 14 Effect of Variability in Yield Force on the Probability of safety

=0.）の結果に比べて約 $4 \%$ 大きいが，その反対に変 動係数は約 $10 \%$ ほど小さい。

Fig. 13 は降伏強度に変動がない完全塑性モデルの $\tilde{W}_{p 1}$ の時刻歴を図示した。応答終了後に予想される $W_{\rho 1}$ がその許容值より小さければ, 構造物の安全性は数値上 $100 \%$ 保障されるが, 降伏強度に変動がある場合は, 保 障されない。Fig.14 は降伏強度に変動があるときの構 造物の安全の確率 (8-11) 式を図示したものである。(a) は C.O.V. $\left[Q_{y 1}\right]=0.069$, C.O.V. $\left[\tilde{W}_{R}\right]=0.069$ であり, (b) は C.O.V. $\left[Q_{y 1}\right]=0.138$, C.O.V. $\left[\tilde{W}_{R}\right]=0.138$ の結 果である。Fig.14の図中の $\tilde{W}_{\rho 1}$ は Fig. $13 の t=20 \mathrm{sec}$ における $\tilde{W}_{p 1}$ の值を意味する。これらの結果から， C.O.V. $\left[Q_{y 1}\right]=$ C.O.V. $\left[\tilde{W}_{R}\right]=0.069$ の場合に構造物の安 全の確率を $95 \%$ 以上保障するためには，累積塑性変形 によって吸収される許容無次元エネルギー入力の平均値 は構造物に生じると予想される值の 1.5 倍必要である。

\section{$\S 10$. 結 論}

不確定性を有する構造部材の復元力特性が履歴振動系 のエネルギー応答に及ぼす影響を明らかにするための解 析的アプローチについて述べた。結果を要約すると次の ようになる。

（1）これまで，材料の不確定性が構造物の芯答に及ぼ す影響に関する研究は, モンテカルロシミュレーション に基づいてなされてきたが，エネルギー応答に関する限
り, 確率変数の平均値で代表された履歴振動系の時刻歴 応答の数值計算を一度だけ実行することによって，この ような問題を解析的に論じることが可能である。

（2）（3-2）式の履歴モデルを有する構造物系八の全体 のエネルギー入力は，地震波に含まれている周晸数成分 とその加速度振幅をもつ調和入力を受けたときの構造物 系へのエネルギー入力の各々の值を重ね合わせることに よって近似的に得られる。

（3）累積塑性変位によって吸収されるエネルギー入力 の変動係数は降伏強度の変動係数の 3 倍強である。

（4）構造物の信頼度関数として(8-1)式を用いた場合, C.o.V. $\left[Q_{y 1}\right]=0.069$, C.o.V. $\left[\tilde{W}_{R}\right]=0.069$ の亡きに構 造物の安全の確率を $95 \%$ 以上保障するためには，累積 塑性変形によって吸収される許容無次元エネルギー入力 の平均値は構造物に生じると予想される值の約 1.5 倍で ある。

（5）最後に，2 質点系の場合に，2 層部分へのエネル ギー入力が小さく， $\tilde{u}_{j}$ が1より小さくなり，正確な収 斂計算を実行することができなかったが， に重み関数 $f\left(\tilde{u}_{j}\right)$ を用いることによって，このような 問題点は解消されると思われる。この問題については今 後の研究課題としたい。

\section{参考文献}

1) Hasofer, A.M., Lind, N.C. : Exact and Invariant Second-Momemt Code Format, Proc., ASCE, EM 1, Feb. 1974

2) Ang, A.H. : Structural Risk Analysis and ReliabilityBased Design, Proc. ASCE, ST 9, Sep., 1973

3) Cornell, C. A. : A Probability-Based Structural Code, Journal of the American Concrete Institute, 1969

4) 洪起, 田中 尚：ホワイトノイズを受ける 1 自由度 系の履歴吸収エネルギ一，日本建築学会論文報告集，第 270 号, pp. 99 - 102, 昭和 53 年 8 月

5) Sues, R. H., Wen, Y. K. and Ang, A. H. : Stochastic Evaluation of Seismic Performance, Journal of the Structural Engineering, ASCE, Vol. 111, june, 1985

6) O'Connor, J., Ellindwood, B. : Reliability of Nonlinear Structures with Seismic Loading, Journal of Structural Engineering, ASCE, Vol. 113 May, 1987

7) Kuwamura, H. : Effect of Yield Ratio on the Ductility of High Strength Steels Under Seismic Loading: Proceeding of the Structural Stability Research Council

8) Kuwamura, H., Kato, B. : Effect of Randomness in Structural Members' Strength on the Structural systems' Ductility, Journal of Construction Steel Research, Vol. V. 1989

9) A.S. Elnashai and M. Chryssanthopoulos: Effect of Random Material Variability of Seismic Design Parameters of Steel Frames, Earthquake Engineering and Structural Dynamics, 1989

10) Baker, M. J. : Variability in the Strength of Structural 
Steels-A Study in the Strutural safty, Part 1: Material Variability, CIRIA Technical Note44, London, 1972

11) Flint, A. R., Smith, B.W., Baker, M. J : The Deviation of Safty Factor for Design of High-way Bridge, in the Design of Steel Bridges, K. C. Rockey \& H.R. Evans, 1981

12) H. Yamanouchi, B. Kato, H. Aoki : Statistical Features of Mechanical Properties of Current japanese steels.

13) Suzuki Y., Minai R. : Seismic Reliability Analysis of Hysteretic Structures Based on Stochastic Differential Equation, Proc., 4th Internationl Conf. Structural Safty and Reliability, Vol.2, 1985

14）大井謙一, 田中 尚, 高梨晃一：地震動による棈造物へ のエネルギー入力の統計的予测に関する基礎的考察, 日 本建築学会構造系論文報告集, 第 347 号, pp. 47 54, 1985 年 1 月
15）洪起，高梨晃一：信頼性理論に基づく最適設計，日 本建築学会構造系論文報告集, 第 418 号, pp. $81 \sim 86$, 1990 年 12 月

16) Papoulis, A. : The Fourier Integral and its Applications, Mcgraw-hill

17) H. Kuwamura, T. V. Galambos: Earthquake Load for Structural Reliability, Journal of Structural Engineering, Vol.115, No.6, June, 1989

18）多治見宏：建築振動学, コロナ社

19）洪起：履歴構造物の耐震安全性解析, 日本建築学会 論文報告集, 第 306 号, 昭和 56 年 8 月

20）大井謙一，高梨晃一：簡単な履歴モデルによる鋼構造骨 組の地震応答解析; 日本建築学会構造系論文報告集, 第 394 号, pp. $37 \sim 46$, 昭和 63 年 12 月

（1991 年 8 月 1 日原稿受理, 1991 年 12 月 27 日採用決定） 